\title{
Intertwining Ambivalence, Multiplicity, and Contingency
}

Keja Valens

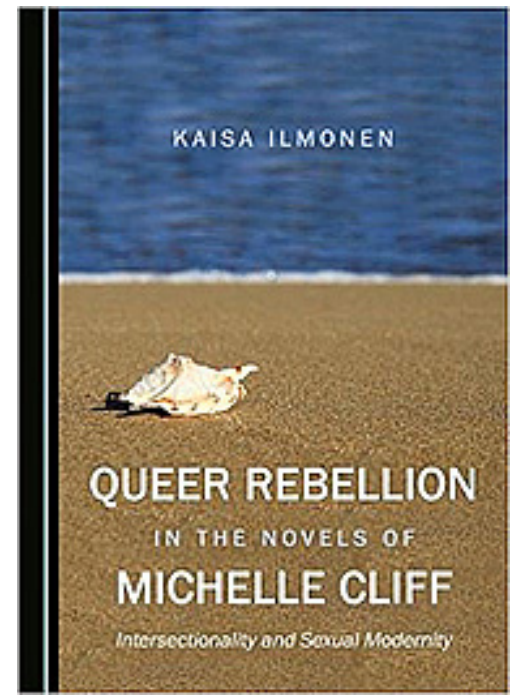

Kaisa Ilmonen. 2017. Queer Rebellion in the Novels of Michelle Cliff: Intersectionality and Sexual Modernity. Cambridge Scholars Publishing, $278 \mathrm{p}$.

Kaisa Ilmonen's Queer Rebellion in the Novels of Michelle Cliff opens slowly, with the first two chapters presenting introductions to the theoretical and critical fields in which it is located and to the works that it engages. Although it could be dismissed as the paraphernalia of a dissertation, which is in the tradition of Cambridge Scholars Publishing this book clearly reproduces, the introduction offers a clear, thorough, wide-ranging, and at the same time remarkably concise overview of the key critical terms at play: the Caribbean, Postcolonial Studies, Caribbean studies, identity, intersectionality, creole, and queer. The introduction may be a bit more of what Ilmonen herself calls a "heavy methodological toolbox" than is needed by an audience interested in the reading of "intersectionality and sexual modernity" in the novels of
Michelle Cliff, but it will be of great service to students in Caribbean, postcolonial, and queer studies courses - indeed the introduction could easily be used as part of a course packet or a reader for such a course. The second chapter of Queer Rebellion opens as the beginning of the analysis, laying out a strong argument for "fiction or history," although its main substance is a set of thorough summaries of Cliff's works and of the criticism that has engaged them.

A reader with knowledge of the contexts and body of Cliff's work might want to start Queer Rebellion at Chapter Three, "Colonialism, Language, and the Imperial Mythos of Modernity" where the analysis begins in earnest. The body of Queer Rebellion, in the tradition of the dissertation, relies heavily on situating Cliff's work and Ilmonen's analysis in the context of other related academic work. For the genre, it is wonderfully thorough and succeeds in drawing together work on Cliff, on the Caribbean, and on colonial and postcolonial studies, although it also buries to a certain extent the wonderful insights and original analyses that Ilmonen offers of Cliff's "queer rebellion." In the tradition of the dissertation, Ilmonen appears hesitant to trust and highlight her own contributions as the focus of her work. At the beginning and end of several sections, however, appear flashes of analyses that both open new readings of Cliff's work and make important interventions in Caribbean and queer studies. At the end of
Queer Eye Reviews 
a section on "The Caribbean as the Flip Side of Colonial Modernity," Ilmonen acutely suggests: "Cliff tries to reach towards a larger dialogue" beyond oppositional representations of "colonial and decolonial ideas" or of Enlightenment and the "Other" (p. 102). Ilmonen refers briefly to a number of ways that Cliff might do this, although rather than fully developing of the claim, Ilmonen rather quickly concludes that Cliff accomplishes this "by rendering visible the ways in which the Caribbean is already intertwined within the project of modernity, which is often considered European" (p. 102).

At several key moments, Queer Rebellion breaks free from its contextualizing constraints to eloquently elaborate its most important claims through close readings of Cliff's work. Deftly drawing on Barthes' and Derrida's work on mythology and whiteness, along with a clear analysis of colonial color hierarchies and their confluence with moral and developmental hierarchies, Ilmonen examines how in Abeng "white mythology" insidiously directs Jamaican girls' understanding of their own racial and sexual positions and even as "white mythology" is used "to protect the family in the colonial reality divided by shades of skin color" leading to the incisive conclusion that "the imperial mythology interpellated colonial subjects ambiguously. On the one hand, they were made to believe that they belonged to the same commonwealth family, while on the other hand it was made clear that they were different. This is the ambivalence of the colonial logic of mimicry. Consequently, "the Creole' simultaneously signified both sameness and difference" (p. 107). Ilmonen then connects a rich analysis of Abeng's critiques of white(r)ness as advancement to the questions of (re)writing history that she treats in Chapter Two, identifying and analyzing characters and moments that "crystallize the rebellious ethos of [Abeng] not only in terms of action, but also in terms of identity construction" and the ways that No Telephone to Heaven "envisions counter-mythologies" (p. 111).
Presenting an important twist on the question of using the master's tools (here, linguistic) to dismantle the master's house, Ilmonen proposes "dismantling the master's tools" to describe Cliff's use of code-switching as part of a rebellion by which the Caribbean woman moves herself from the "spoken subject" to the "speaking subject" (p. 115). Ilmonen's ability to weave together seemingly opposing analyses of Cliff's work shines here as she examines how "the code-switching in Cliff's novels also reflects the Caribbean as a site of multicultural encounters" (p. 115). Eschewing "the simple binary between dominant and minority discourse" that has marked some scholarship, Ilmonen embraces the understanding that "neither minority discourse nor dominant discourse is homogenous and stable" to study Cliff's use of language as "a strategic tool for rebellion and textual resistance" that abrogates and appropriates colonial language and thus "opens up a further means of dialog rather than stabilizing discursive boundaries" (p. 117). Cliff's dialog, Ilmonen clarifies, invokes disturbance as much as solidarity, operating a rebellious interpellation of Caribbean subjectivity to open "creolized agency" for non-heterosexual as well as non-white voices (p. 120). As she does this, Ilmonen deftly builds her argument on the ground laid by Homi Bhabha, Michel Foucault, Henry Louise Gates, Jr., Édouard Glissant, and others, having moved from the tendency in the first two chapters to bury her arguments in those of others she shows her own voice to emerge out of a critical conversation not unlike the ones that she charts for Cliff's characters.

Both a strength and a weakness of Queer Rebellion is its attempt to fit everything in and to fit everything together. The multiple and intersecting vectors of Caribbean studies, postcolonial studies, feminisms, Africana studies, queer studies, and Cliff's novels are present throughout Queer Rebellion, and it can be difficult to find the critical path that the book offers. Queer Rebellion is at its best when Ilmonen uses her extensive research to acutely position Cliff's work in relation to other literary works and

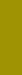


to analyses of them. In Chapter Five "Mothers, Grandmothers, and the Matrilineal Counter-History," for example, Ilmonen argues that Cliff's work "widens the boundaries of motherhood" (p. 183) so that when Cliff traces coming to love the mother as coming to love the mother-land, rather than praising origins or biological (and heterosexual) motherhood, Cliff constitutes "the feminist genealogy of Caribbean women's resistance" that Cliff's daughter characters recuperate and join (p. 185) so that "it is the rise of the resisting feminist daughterhood that epitomizes the ethos of Cliff's decolonial textual rebellion” (p. 192).

While Ilmonen's "identity poetics" and queer readings of Cliff's novels in Chapter Six "From Sexual Identity Poetics to Intersectional Queer Practices" do not stand out from other such readings that Ilmonen cites, this chapter offers a frame where "my queer reading of Cliff's novels also becomes an interpretation of the theoretical context it draws on" (p. 200) that deftly mirrors Ilmonen's argument that Cliff's novels are poetic interventions in the political, philosophical, and cultural contexts they draw on. This frame offers a way to understand the whole book's project as not just an interpretation of Cliff in the context of so many others, but an interpretation of the contexts of Caribbean, postcolonial, feminist, and queer theories it draws on. In both the chapter and the book, there could be less cataloging and more interpreting. Nonetheless, the cataloging is necessary for the interpretation and the strengths of Ilmonen's interpretation-like the understanding of "queer transnationality" as based on "queer identifications, not as universalist categorizations, but as multiply located positions" (p. 225) or the insistence on how Cliff "does not tire of representing queer diasporic positionalities describing the intersecting and co-constitutive categories of ethnicity, gender, class, and sexuality in a constant flux" (p. 237) — suggest that more of the latter is to be expected from Ilmonen.
If Queer Rebellion's introduction offers the novice reader a strong overview of the book's theoretical and literary contexts, the conclusion is where scholars already invested in Caribbean and queer studies can find a clear articulation of Ilmonen's compelling arguments. The conclusion concisely argues that Cliff's novels belie her own dream of creating "a complete Caribbean woman" to instead "represent identities in constant, intersectional flux" in ways that rebel against the totalizing and reductive forces of colonial history and many Western interpretive modes and create instead "a discursive space where $[\ldots]$ intersectional identifications are possible" and where they are localized, dialectic, contingent, transnational, decolonial, transtemporal, and queer (p. 244). Furthermore, the discursive space of Cliff's novels enacts "a dialog between oppressive and healing discourses within which the creolized, (post) colonial queer subject gains agency" (p. 245). The conclusion demonstrates that Ilmonen's study of Cliff's work performs what it posits as Cliff's own "emphasis on mixtures and crossovers [that] is an ethical deed in a contemporary multicultural reality" (p. 244). 